\title{
Developing Intercultural Communicative Competence in Foreign Language Learning
}

\author{
Hye-Yeon Lim ${ }^{1, *}$, W. I. Griffith ${ }^{2}$ \\ ${ }^{1}$ Defense Language Institute Foreign Language Center, USA ${ }^{\mathrm{i}}$ \\ ${ }^{2}$ The University of Texas at Austin (Retired), USA
}

Copyright $\bigcirc 2016$ by authors, all rights reserved. Authors agree that this article remains permanently open access under the terms of the Creative Commons Attribution License 4.0 International License

\begin{abstract}
Successful foreign language learners need to have intercultural communicative competence that goes beyond linguistic knowledge. This paper focuses on designing activities that promote intercultural communicative competence in foreign language learning. Competence in intercultural communication requires an understanding of both the L1 and L2 cultures. Using the Interagency Language Roundtable (ILR) [1] skill levels, this paper looks at the role of intercultural competence in developing effective cross-cultural communication. The paper presents lesson activities designed to build such intercultural competence from the elementary through professional working competency levels as defined by the ILR scale. The sample activities address specific cultural objectives, activate higher-order critical thinking skills, and have the added advantage of allowing teachers to recycle information to anchor and reinforce existing knowledge.
\end{abstract}

Keywords Intercultural Communicative Competence, Foreign Language Education, Interagency Language Roundtable (ILR) Skill Levels

\section{Introduction}

The purpose of learning a language, including a foreign language, is to communicate with others. Effective communication requires the ability to function in communicative settings [2-5] and requires more than knowing what (vocabulary) to say and how (grammar) to say it. Individuals must also know when to say something, to whom it should be said, and why it must be said. These five elements - how, why, when, where and to whom-must all function together in order to be able to communicate with others in a meaningful way.

The relationship between language and culture, as well as the role of cultural competence in communicative competence has come increasingly under study. Educators have gained a greater appreciation for the role culture plays in language acquisition. Many now believe that language learning is, in many respects, cultural learning [cf. 6-9].

Data have demonstrated that language and culture are closely related [10-15]. Vocabulary and grammar only partially structure the nature of communication. Extra-linguistic elements such as values, beliefs, norms, rituals, and traditions are also key components of communication exchanges [1]. Evidence increasingly supports the notion that teaching culture in foreign language classrooms enhances communicative competence [2,3,16-22]. Achieving higher levels of language proficiency depends on thinking like a target language speaker and such thinking requires cultural understanding. Brown [10] clearly reinforced this belief when he stated

...that one cannot separate the two without losing the significance of either language or culture. The acquisition of a second language, except for specialized, instrumental acquisition [...], is also the acquisition of a second culture [pp. 189-190].

\section{Intercultural Communicative Competence and Language Proficiency}

Vocabulary acquisition is arguably the basic building block of foreign language acquisition. For many, this process involves memorizing long lists of words, often with their English counterparts. Words, however, have more than denotative meanings. Words also have connotative meanings that depend on cultural proscriptions to interpret correctly. Knowing about the culture of a society (i.e. cultural competence) can help to cement vocabulary in the memory of the learner and to increase the accuracy of its use. In this sense, understanding the cultural basis of vocabulary can take the student beyond "book" or "classroom" language to more authentic and accurate language.

Intercultural communicative competence refers to an individual's ability to navigate within a given society 
appropriately. In other words, individuals are able to use appropriate gestures, understand the unspoken meaning in words, appreciate the cultural underpinnings in any communication, and make appropriate cultural references to aid in understanding. For example, an individual may well come to understand the power relations between two actors based on various physical gestures and language. Register and tone can serve as indicators of the emotional affect between speakers or the level of trust.

Intercultural competence can help drive home the grammar rules of any language. For example, tenses are intimately related to cultural views and constructs of time. Different cultures conceive of the concept of time in different ways. Some languages (e.g. Chinese and Indonesian) lack grammatical verb tenses. Verb forms do not change but, rather, express time through the use of adverbs or the addition of special particles [23,24]. These cultural features make it difficult to understand time distinctions that differ from or are absent from the speaker's own cultural orientation. An understanding of a given culture's constructs of time should help learners correctly assimilate the usage of tenses [25].

At this point, it is critical to understand the difference between two key concepts: cultural competence and intercultural communicative competence. Cultural competence involves the knowledge of a specific culture including factual knowledge history, mores, folkways, and values of a society. Intercultural communicative competence, on the other hand, includes these same variables with the additional requirement that an individual be able to use this knowledge in combination with linguistic, sociolinguistic, and discourse competencies to create a meaningful and proper communication whose message will be easily intelligible to another $[2,3,26]$.

Intercultural communicative competence is a key factor in effective cross-cultural communication. Intercultural communicative competence requires not only that learners know about the target language culture but about their own culture [27] and its effects on behavior, thoughts, perceptions, etc. In other words, true competence in intercultural communication requires that an individual have active knowledge of both his/her own culture as well as that of the target language culture. In developing this competence, one needs to activate higher order critical thinking skills to understand the effects of culture on individuals and promote self-awareness. That is, cultural knowledge must go beyond a simple compendium of facts about the target culture. Instead, learners should be exposed to activities that focus on helping students to understand their own culture and evaluating the similarities and differences between their own and the target culture [27,28].

Competence in intercultural communication can be measured along a continuum. The Interagency Language Roundtable (ILR) [1] has established a series of guidelines that measure intercultural communicative competence along a five point scale where 0 indicates no competence and 5 indicates superior professional competence. Within this framework, intercultural communicative competence refers to the content and the form of communication and includes both the verbal and nonverbal aspects. That is, there is a correspondence between the level of language proficiency and the level of intercultural competence. To achieve a given level of cultural competence, one must also have a corresponding level of language proficiency. A weakness in either dimension can hinder the achievement level in the other [1].

The table below is a brief summary of the levels of intercultural communicative competence and correspondent linguistic proficiency. The summary is intended to be illustrative rather than a complete elaboration of the characteristics and skills needed to achieve any given level. For a more complete elaboration of these as well as descriptors, please refer to ILR [1]. 
Table 1. ILR Skill Levels Summary for Intercultural Communication and Linguistic Competence

\begin{tabular}{|c|c|c|}
\hline $\begin{array}{c}\text { Levels of } \\
\text { Competence }\end{array}$ & Intercultural Communication & Linguistic Competence \\
\hline $\begin{array}{c}\text { ILR Level } 0 \\
\text { (No Competence) }\end{array}$ & $\begin{array}{l}\text { Little knowledge or awareness of cultural differences. Unable to } \\
\text { adjust when faced with differences. }\end{array}$ & No familiarity with foreign vocabulary or grammar. \\
\hline $\begin{array}{l}\text { ILR Level } 0+ \\
\text { (Memorized } \\
\text { Competence) }\end{array}$ & $\begin{array}{c}\text { Can engage in rehearsed behavior and memorized patterns; has a } \\
\text { vague awareness of the differences between own and target } \\
\text { language culture; can avoid some cultural taboos; can handle } \\
\text { routine introductions, greetings, statements of appreciation, and } \\
\text { apology. }\end{array}$ & $\begin{array}{l}\text { Has a basic command of some words and phrases but } \\
\text { lacks understanding of social conventions of } \\
\text { conversation; can understand short and memorized } \\
\text { utterances; knows the basic characters of the written } \\
\text { system; can recognize isolate words and phrases, } \\
\text { numbers, place names, and shops or office designations. }\end{array}$ \\
\hline $\begin{array}{l}\text { ILR Level } 1 \\
\text { (Elementary } \\
\text { Competence) }\end{array}$ & $\begin{array}{l}\text { Able to participate in everyday interactions but not always using } \\
\text { acceptable behavior; recognizes the differences between cultures } \\
\text { but does not comprehend their significance; aware of basic } \\
\text { courtesies and paralanguage. }\end{array}$ & $\begin{array}{l}\text { Has a command of basic vocabulary sufficient to satisfy } \\
\text { basic and routine needs; can understand and use basic } \\
\text { courtesies; can deal with familiar topics. }\end{array}$ \\
\hline $\begin{array}{l}\text { ILR Level } 2 \\
\text { (Limited Working } \\
\text { Competence) }\end{array}$ & $\begin{array}{l}\text { Able to handle most routine situations; demonstrates cognizance } \\
\text { of differences between cultures; avoids most cultural taboos and } \\
\text { conforms to general standards of etiquette; has some ability to } \\
\text { reference issues and topics related to history, culture, and current } \\
\text { events. }\end{array}$ & $\begin{array}{c}\text { Commands grammar and vocabulary sufficient to satisfy } \\
\text { routine social demands and limited work requirements; } \\
\text { understands the gist of conversations; handles most } \\
\text { social situations. }\end{array}$ \\
\hline $\begin{array}{l}\text { ILR Level } 3 \\
\text { (Professional } \\
\text { Competence) }\end{array}$ & $\begin{array}{c}\text { Ability to participate in most interactions and transfer between } \\
\text { formal and informal situations; rarely misreads cultural cues and } \\
\text { can understand and make a variety of cultural references; } \\
\text { demonstrates significant knowledge and understandings of } \\
\text { cultural expectations. }\end{array}$ & $\begin{array}{l}\text { Commands linguistic skills sufficient to participate in } \\
\text { formal and informal conversations on a variety of topics; } \\
\text { capable of comprehending normal rates of speech, rarely } \\
\text { has grammar problems which impede comprehensibility. }\end{array}$ \\
\hline $\begin{array}{l}\text { ILR Level } 4 \\
\text { (Advanced } \\
\text { Professional } \\
\text { Competence) }\end{array}$ & $\begin{array}{l}\text { Ability to control the full range of formal and informal language } \\
\text { and behavior; correctly interprets cues, cultural allusions, } \\
\text { nuances, tones, and underlying cultural values; possesses in-depth } \\
\text { knowledge of traditions, beliefs, history, national issues, and } \\
\text { policies. }\end{array}$ & $\begin{array}{l}\text { Able to use the language fluently and accurately; makes } \\
\text { only un-patterned errors in grammar and pronunciation; } \\
\text { can handle informal interpreting between languages. }\end{array}$ \\
\hline $\begin{array}{l}\text { ILR Level } 5 \\
\text { (Superior } \\
\text { Professional } \\
\text { Competence) }\end{array}$ & $\begin{array}{l}\text { Has the cultural proficiency of a native; able to recognize and } \\
\text { understand colloquialisms, regionalisms, slang, and cultural } \\
\text { references; understands and can analyze various aspects of culture } \\
\text { and its underpinnings. }\end{array}$ & $\begin{array}{l}\text { Has a speaking proficiency equivalent to that of an } \\
\text { educated native speaker including a command of a wide } \\
\text { vocabulary, idioms, and cultural references. }\end{array}$ \\
\hline
\end{tabular}

\section{Building Critical Thinking Skills}

The achievement of intercultural communicative competence depends on the development of critical or higher-order thinking skills including comparing, assessing, evaluating, and synthesizing [27]. Critical thinking is a key component in the development of advanced levels of intercultural communicative competence. To communicate with greater proficiency, learners must have critical cultural awareness. That is, they must recognize the cultural context, and the cultural proscriptions that bound the interactions, including the use of specific language and register. In this context, critical thinking refers to the ability to apply previously learned information in new or novel ways and situations. One of the most well-recognized schemata representing critical thinking is Bloom's taxonomy [29,30].

Critical thinking is central to effective communication since it allows participants to analyze, evaluate, and act upon communication cues including words, gestures, and other paralinguistic features. Effective communicators are able to determine the relevant (and irrelevant) aspects of communication in order to respond in meaningful ways. Knowledge of both their own and others' cultures allows speakers to anticipate communication/cultural misunderstandings and navigate a path that minimizes these issues. Critical thinking can help individuals understand each person's role in the communication and adjust to the situational demands [31]. Therefore, effective activities promoting a higher level of intercultural communicative competence should employ three features: use of pertinent linguistic elements (including vocabulary and grammar forms); create/enhance awareness of both the L1 (native language) and L2 (second/foreign language) cultures; and require critical thinking skills to complete tasks. These skill sets can be developed through appropriate and intentional class activities [18,32-34].

\section{Applying Intercultural Communicative Competence to Classroom Activities}

Below are several examples showing how activities building intercultural communicative competence can be included in the classroom at all levels. The examples are arranged by topic area. The level indicated in the activity identifies the level of competence in intercultural communication and also reflects the relative language skills needed. It is not essential that these activities be conducted entirely in the target language. In fact, because the focus is on intercultural awareness and development, it can be appropriate to use the learner's native language, especially in 
the beginning stages of learning. As the student progresses linguistically, the tasks may also require greater dependence on the target language.

These activities are designed to address specific cultural objectives to increase awareness and knowledge of L1 and L2 cultures. The linguistic competence required to complete each activity is roughly correspondent to the level of cultural competence noted. This means that, for example, a level three or higher objective should not be introduced at the beginning of a course because it requires a higher level of language proficiency than the student is likely to have. Therefore, activities with higher levels of proficiency can be introduced later in the curriculum as the student progresses. An added advantage of this approach is that it allows teachers to recycle information learned earlier in the course which should serve to both anchor and reinforce existing knowledge.

\subsection{Introductions and Salutations}

\subsubsection{ILR Level 0+: Naming practices and conventions in the target language (TL) country}

Students understand the word order of names and correctly identify family names, given names, and patronyms where relevant. Students detail the naming conventions in their own family or nation and compare them with those of the TL country. They may also discuss the importance of names in both countries and the role of names in individual identity. Using the naming conventions of the TL country, students decide what their name might have been if those conventions had been employed (e.g. named after their paternal grandfather). Students represent their actual names in the TL country style (e.g. in South Korea, James Johnson would be Johnson James). [According to Bloom's revised taxonomy, the following skills are necessary to complete the activity: remembering factual knowledge, understanding, and applying.]

\subsubsection{ILR Level 1/1+: Conventions for greetings and interactions based on social status}

Students work together in pairs. Each pair receives information about the relative status, rank, sex, and age of two people. After reading the information, students then greet each other using the appropriate language, titles, gestures (e.g. hand shake, bow, eye contact, etc.). Students record their brief interaction and other students (or the teacher) can evaluate it for cultural appropriateness and language skill. [According to Bloom's revised taxonomy, the following skills are necessary to complete the activity: remembering factual and conceptual knowledge, understanding, applying, and analyzing.]

\subsubsection{ILR Level 2/2+: Understanding social relationships based on dialog and gestures}

The teacher provides a set of dialogs with illustrations or video dialogs that include gestures. Students then recall what happened, identify the speakers' relationships to each other, and create a similar dialog varying the relationship of the speakers (including appropriate gestures and linguistic forms). [According to Bloom's revised taxonomy, the following skills are necessary to complete the activity: remembering factual knowledge, understanding, applying, and analyzing.]

\subsubsection{ILR Level 3 or Higher: Comparing and analyzing naming practices and the importance of names in cultures}

Using the target language, students discuss how they got their own names, naming practices in their own families, and the importance of names and the use of names in their native language. Students then compare/contrast these with those of the TL country. Include the significance of names and their relationship to key values in the TL country culture. [According to Bloom's revised taxonomy, the following skills are necessary to complete the activity: remembering factual, conceptual, and procedural knowledge, understanding, applying, analyzing, and evaluating.]

\subsection{People and Appearances}

\subsubsection{ILR Level 0+: Recognizing the relation between clothing and social/ethnic identification}

In some countries clothing may indicate social status, ethnic or tribal affiliation, or religious affiliation. Students work in pairs or small groups. After receiving a series of pictures, one student describes people in the picture including their dress and any social information (e.g. male vs. female, age) to his/her colleague(s). Using that information, the other group members determine the person's social status, tribal and/or ethnic affiliation, and other social information conveyed by the dress. [According to Bloom's revised taxonomy, the following skills are necessary to complete the activity: remembering factual knowledge and understanding.]

\subsubsection{ILR Level 1/1+: Family relationships}

Students create a family tree for their own family which includes three generations. They create an imaginary family tree for a typical TL family going back three generations using names and titles (e.g. aunt, grandfather, names that include both given and family names). Students post their family trees. Students include information on the roles and responsibilities of family members in the TL country. [According to Bloom's revised taxonomy, the following skills are necessary to complete the activity: remembering factual knowledge, understanding, and applying.]

\subsubsection{ILR Level $2 / 2+$ : Understanding the differences in family structures between their own and the TL country}

Students compare and contrast the typical household and family unit in the TL country with that of the Unites States. 
The comparison should include major elements regarding the type of family (e.g. nuclear, extended; kinship relations; size of typical family). [According to Bloom's revised taxonomy, the following skills are necessary to complete the activity: remembering factual knowledge, understanding, applying, and analyzing.]

\subsubsection{ILR Level 3 and Higher: Understanding the differences in cultural values between their own and the TL country}

Students compare and contrast the cultural values and characteristics of the TL country with that of the United States. Students are introduced to various scenarios where people's different perceptions play major role in interpreting situations and students learn to apply appropriate interpretations to mitigate potential tensions caused by inappropriate discourse and actions (e.g. family gatherings, business deals). [According to Bloom's revised taxonomy, the following skills are necessary to complete the activity: remembering factual, conceptual, and procedural knowledge, understanding, applying, analyzing, and evaluating.]

\subsection{Geography, Climate, and Weather}

\subsubsection{ILR Level 0+: Identifying and describing important topographical or geographical features}

Students select one major geographical region or topographical feature to research on the internet. Students prepare a visual or graphic listing the main details (e.g. area, elevation, average weather, climate, population density, economic activities). They can post these visuals in the classroom for others to share. [According to Bloom's revised taxonomy, the following skills are necessary to complete the activity: remembering factual knowledge and understanding.]

\subsubsection{ILR Level 1/1+: Recognizing differences in climate and geography}

Students compare a geographical region in the target nation with the geographic region of their home city or state. Information should include basic terrain features, climate, seasons, etc. Students then create a side-by-side comparison of the two regions using a table or slide or brochure. Students can also prepare a guide for travel to a certain city or region including weather for each season and weather charts. [According to Bloom's revised taxonomy, the following skills are necessary to complete the activity: remembering factual knowledge, understanding, and applying.]

\subsubsection{ILR Level 2/2+: Analyzing relationships between weather and terrain and their impact on life styles}

Students explore the relationships between weather, terrain, and lifestyles in the TL country to present to the class. This includes a discussion of any environmental changes or problems caused by weather, and ways in which the population deals with those problems. [According to Bloom's revised taxonomy, the following skills are necessary to complete the activity: remembering factual knowledge, understanding, applying, and analyzing.]

\subsubsection{ILR Level 3 and Higher: Understanding the effects of} geography on lifestyle and social organizations

Students discuss the effects of geography and topography on lifestyles between one region in the TL country and one selected for comparison in the United States. [According to Bloom's revised taxonomy, the following skills are necessary to complete the activity: remembering factual, conceptual, and procedural knowledge, understanding, applying, analyzing, and evaluating.]

\section{Conclusions}

Knowledge of vocabulary and grammatical structures are insufficient to guarantee effective communication. Language carries meaning beyond the words themselves. It also communicates information about the culture of the individuals involved in any communication act because language is inextricably linked with culture. Linguistic knowledge absent corresponding cultural knowledge may mean that students are learning little more than empty symbols to which incorrect interpretations or meanings may be attached. Linguistic proficiency without correspondent intercultural competence can lead to ineffective communications. To truly acquire higher levels of linguistic skills, one must become proficient in both the language and the culture in which it operates.

Competence in intercultural communication requires understanding of both the L1 and L2 cultures. Awareness of the learners' own culture is most likely to be a stepping stone to understanding the differences and similarities between cultures. Class activities that are geared to enhancing such intercultural competence are important for the development of higher levels of language proficiency. Such class activities will provide students with another opportunity to activate critical thinking skills, which in turn, promote better understanding of the target culture and language and build greater intercultural communicative competence.

\section{REFERENCES}

[1] Interagency Language Roundtable (ILR) Skill Level Descriptions for Competence in Intercultural Communication, Online available from http://www.govtilr.org/skills/compete nce.htm

[2] M. Canale. From communicative competency to communicative language pedagogy, In J. C. Richards \& R. Schmidt (eds.), Language and Communication (pp. 2-27), Longman, London, UK, 1983. 
[3] M. Canale, M. Swain. Theoretical bases of communicative approach to second language teaching and testing, Applied Linguistics, Vol. 1, No1, 1-47, 1980.

[4] S. J. Savignon. Communicative competence: An experiment in foreign language teaching, Center for Curriculum Development, Philadelphia, 1972.

[5] S. J. Savignon. Communicative Competence: Theory and Classroom Practice, Addison-Wesley, Reading, MA, 1983.

[6] M. Byram. Cultural studies in foreign language education, Multilingual Matters, Clevedon, UK, 1989.

[7] F. Guessabi. Blurring the line between language and culture, Online available from http://languagemagazine.com/?page_i $\mathrm{d}=2103$

[8] C. Kramsch. Context and Culture in Language Teaching, Oxford University Press, Oxford, UK, 1993.

[9] A. J. Liddicoat, A. Scarino. Intercultural Language Teaching and Learning, Wiley Blackwell, Oxford, UK, 2013

[10] H. D. Brown. Principles of Language Learning and Teaching (5th ed.), Longman, White Plains, NY, 2007.

[11] C. Kramsch. Language and Culture, Oxford University Press, Oxford, UK, 1998.

[12] J. F. Kuang. Developing students' cultural awareness through foreign language teaching, Sino-US English Teaching, Vol. 4, No. 12, 74-81, 2007.

[13] S. J. Savignon, P. V. Sysoyev. Cultures and comparisons: Strategies for learners, Foreign Language Annals, Vol. 38, No. 3, 357-365, 2005.

[14] R. A. Schulz. The challenge of assessing cultural understanding in the context of foreign language instruction, Foreign Language Annals, Vol. 40, No. 1, 9-26, 2007.

[15] Y. Tang. Language, truth, and literary interpretation: A cross-cultural examination, Journal of the History of Ideas, Vol. 60, 1-20, 1999.

[16] H. Hammerly. Synthesis in Second Language Teaching: An Introduction to Linguistics, Second language publications, Blaine, Washington, 1982.

[17] H.-Y. Lim, W. I. Griffith. Idiom instruction through multimedia and cultural concepts, Dimension, 43-51, 2002.

[18] H.-Y. Lim, W. I. Griffith. Developing intercultural communication competency in foreign language learning, Fifth International Conference on the Development and Assessment of Intercultural Competence, Tucson, University of Arizona, Jan. 2016.

[19] S. J. Savignon. Communicative language teaching: Linguistic theory and classroom practice, pp. 1-28, In S. J. Savignon (ed.), Interpreting Communicative Language Teaching:
Contexts and Concerns in Teacher Education, Yale University Press, New Haven, CT, 2002.

[20] S. J. Savignon, P. V. Sysoyev. Sociocultural strategies for a dialogue of cultures, Modern Language Journal, Vol. 86, No. 4, 508-524, 2002.

[21] H. H. Stern. Fundamental Concepts of Language Teaching, Oxford University Press, Oxford, UK, 1983.

[22] A. Omaggio. Teaching Language in Context (3rd ed.), Heinle and Heinle, Boston, MA, 2001.

[23] E. Hinkle. L2 Tense and time reference, TESOL Quarterly, Vol. 26, No. 3, 557-572, 1992.

[24] J. Wagner. Verbs in Indonesian — present, past, future tenses. Online available from $\mathrm{http}$ ://ielanguages.com/lessons/verbs-i n-indonesian/

[25] L. Boroditsky. How does our language shape the way we think? Online available from https://www.edge.org/conversa tion/lera boroditsky-how-does-our-language-shape-the-waywe-think

[26] M. Byram. Intercultural competence in foreign languages The intercultural speaker and the pedagogy of foreign language education, In D. K. Deardorff (ed.), The SAGE Handbook of Intercultural Competence (pp. 321-332). SAGE Publications, Thousand Oaks, CA, 2009.

[27] D. K. Deardorff (ed.) The SAGE Handbook of Intercultural Competence, SAGE Publications, Thousand Oaks, CA, 2009.

[28] B. H. Spitzberg, G. Changnon. Conceptualizing intercultural competence, In D. K. Deardorff (ed.) The SAGE Handbook of Intercultural Competence (pp. 2-52), SAGE Publications, Thousand Oaks, CA, 2009.

[29] B. S. Bloom. Taxonomy of Educational Objectives, Handbook 1: The Cognitive Domain, David McKay, New York, 1956.

[30] L. W. Anderson, D. R. Krathwohl. A Taxonomy for Learning, Teaching, and Assessing: A Revision of Bloom's Taxonomy of Educational Objectives. Longman, New York, 2001.

[31] M. Khatami, M. Hassankiadeh. Critical thinking and intercultural communication in learning environments, Enjoy Teaching Journal, Vol. 3, No. 4, 1-12. 2015.

[32] W. I. Griffith, H.-Y. Lim. Making student-centered teaching work, MexTESOL Journal, Vol. 34, No. 1, 75-83, 2010.

[33] W. I. Griffith, H.-Y. Lim. Introduction to competency-based language teaching, MexTESOL Journal, Vol. 38, No. 2, 1-9, 2014.

[34] H.-Y. Lim, W. I. Griffith. Practice doesn't make perfect, MexTESOL Journal, Vol. 35, No. 1, 1-9, 2011.

i The views expressed are my own and do not reflect the official policy or position of the Defense Language Institute Foreign Language Center, Department of Defense, or the U.S. Government. 